\title{
PROPUESTAS ESTÉTICAS, (I)LÓGICAS NARRATIVAS Y VETAS TEMÁTICAS EN EL SENO DE UNA CIERTA FICCIÓN TELEVISIVA CONTEMPORÁNEA
}

Data recepción: 2012/05/16

Xosé Nogueira

Data aceptación: 2012/06/28

Universidade de Santiago de Compostela

Contacto autor: xose.nogueira@usc.es

\section{RESUMEN}

Se propone en este texto un recorrido por las transformaciones (industriales, artísticas, narrativas) que ha conocido una importante vertiente de la ficción televisiva actual, las cuales la han llevado a convertirse (a ella y a sus creadores) en una fuente de textos decisiva tanto para conocer algunas de las mejores manifestaciones que está ofreciendo nuestra cultura audiovisual (y para entender el audiovisual mismo) como para auscultar de forma audaz el estado en el que se encuentra nuestra contemporaneidad.

Palabras clave: cine y televisión, complejidad, deconstrucción, disolución, hibridación, hipermodernidad, identidad, intertextualidad, imaginario(s), locura, mutación, neorrelato, posmodernidad.

\section{ABSTRACT}

This text looks at the industrial, artistic and narrative transformations that a sizeable proportion of modern-day television fiction has undergone. These transformations have led to said body of work and its creators becoming an essential textual source for approaching some of the finest work being generated by our audiovisual culture (and for understanding the audiovisual medium itself), and for offering a bold appraisal of the current state of our contemporaneity.

Keywords: cinema and television, complexity, deconstruction, dissolution, hybridisation, hypermodernity, identity, intertextuality, imaginary world(s), madness, mutation, neo-story, postmodernism.

\section{Intro.}

De entrada, se impone la necesidad de un acotamiento dirigido al lector. Este texto parte de una propuesta1, la de intentar articular una reflexión sobre los (significativos) cambios que han tenido lugar en la estética y estructura narrativa de las series televisivas a lo largo de las dos últimas decadas, así como sobre sus temáticas, que forzosamente -dadas las limitaciones de espacio- deberemos orientar, de cara a intentar hacerla mínimamente operativa, hacia un cierto tipo de ficción serial televisiva.

¿Qué tipo de ficción, entonces? Pues nos centraremos en la servida por las series estado- unidenses por motivos obvios ya que, como es ya sabido -salvando el especial caso británico, bastante más reciente, u otros casos muy puntuales a los que haremos referencia muy de pasada-, es en ellas donde se encuentra el territorio en el que podemos hallar las respuestas a nuestra búsqueda.

Evidentemente, no vamos a abordar toda esa producción en conjunto (así tampoco podríamos llegar a nada concreto), de manera que nos centraremos prioritariamente en los shows -por utilizar la terminología anglosajona- de carácter o género drámático $(0$, al menos, en algunos de ellos), entendido en el sentido más amplio del término. Series que normalmente se alojarán en 
origen en los canales de pago/de cable premium que no dependen de los ingresos publicitarios (HBO, TCM, AMC, Showtime y demás; aunque no sólo), que serán los que las produzcan (los que, en realidad, puedan producirlas, si bien en los últimos tiempos están surgiendo nuevos nichos a través plataformas de streaming como Netflix). Y series destinadas, al menos en principio, hacia un cierto tipo de público, con un concreto target de edad (aproximadamente, entre los 25 y 55 años) y determinadas características socio-culturales; un público que, a mayores, ha ido forjando nuevos hábitos y formas de consumo de este tipo de productos. Series que, además, serán seriales (es decir, alternativas a la estructura por episodios), cuando no directamente miniseries.

En definitiva, fijaremos nuestra atención casi en su totalidad en creaciones alejadas de todo conservadurismo conceptual o industrial (ése que, por lo demás, tanto está lastrando a la gran industria cinematográfica norteamericana, la destinada a las grandes cadenas de salas, desde hace años; de ahí los traslados cada vez más frecuentes y numerosos de cineastas a este terreno, como veremos). Porque este es el terreno, advirtámoslo desde el principio, en el que se está gestando a lo largo de los últimos años, una buena parte de lo más inteligente, sustancioso y sofisticado de la ficción audiovisual contemporánea.

\section{Un inicio.}

Quizás todo comenzó en un lugar llamado Twin Peaks (Fig. 1) y, por el momento, hoy podemos estar -entre otras posibilidades- en la Nueva Orleans post-Katrina (Fig. 2). Al fin y al cabo, argumentos situados en el mismo caos ambiental, la misma pérdida de orientación, la misma sensación del fin de toda lógica; e idéntica voluntad de complejidad narrativa (y aquí, la famosa consigna de David Simon, uno de los creadores más influyentes de la ficción televisiva contemporánea (y co-creador de Tremé): "Fuck the average reader / Que se joda el lector [iespectador?] medio"2; cabe pensar/suponer que una idea parecida guía a David Lynch desde el comienzo de su carrera). Si bien, obviamente, esas equivalencias se van a dar en registros distintos, como distintos son los ámbitos en los que localizan sus acciones: la small town, la pequeña

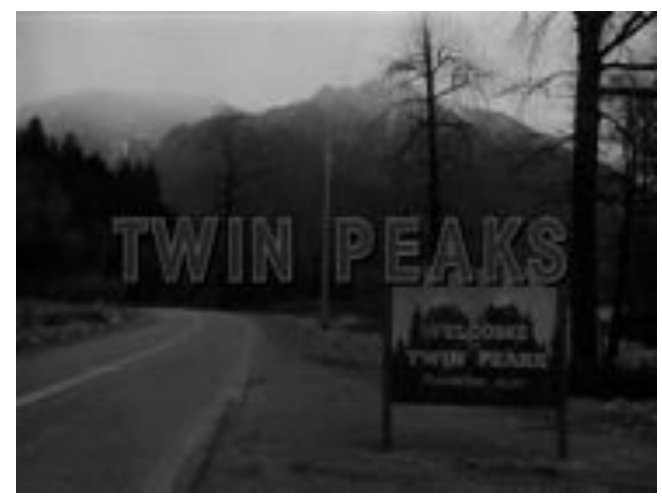

Fig. 1: Twin Peaks.

comunidad estadounidense (en el primero de los casos); la ciudad, una ciudad referencial como es Nueva Orleans (en el segundo). Una división cuya confrontación conceptual nos interesará, como más abajo veremos.

De manera que, entre medias, podremos trazar un trayecto. Un trayecto que, en definitiva, también podría ser industrial: aquél que partiría de la network o cadena generalista ( $A B C$, en el caso de Twin Peaks) y culminaría en el especializado canal de cable (y, ya puestos a concretar, en el canal premium de cable, como HBO). Conviene tener presente, como bien apuntaba en su momento Concepción Cascajosa ${ }^{3}$, que la configuración comercial del medio televisivo, responsable de sus virtudes y sus defectos, ha llevado a que, en la televisión, el continente haya definido al contenido, de manera que los canales de cable -sobre todo desde el comienzo de su esplendor hacia finales de los años 90- han ido desarrollando sus producciones (también las que van a centrar aquí prioritariamente nuestra atención, las dramáticas) siguiendo una filosofía

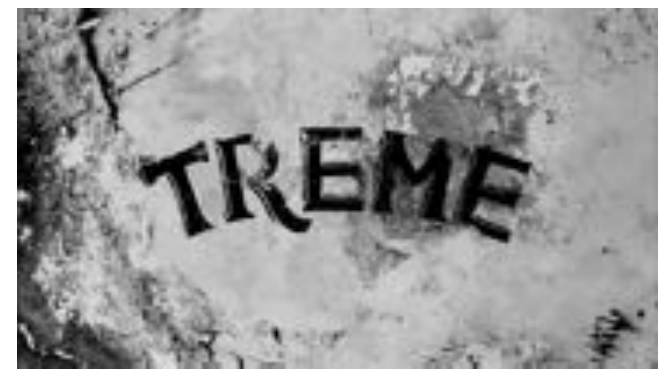

Fig. 2: Tremé. 
y conceptos muy concretos que en muchos casos va a singularizar, a identificar sus contenidos y fórmulas narrativas.

Pero ese trayecto que a priori podríamos proponer sería un trayecto sesgado, que no reflejaría con pertinencia todo lo acaecido -lo realmente acaecido- en el seno de la ficción televisiva norteamericana de los últimos años. De manera que el componente industrial siempre estará ahí, de fondo -lógicamente-, pero no será el único. Porque el panorama y los elementos (creativos, artísticos, industriales, mediáticos) que lo configurarán serán tremendamente heterogéneos, si bien, dentro de esa heterogeneidad, creemos poder localizar una serie de constantes. Va a ser, pues, el nuestro (valga como advertencia previa) un itinerario entre muchos otros posibles, enfocado hacia las cuestiones que más nos interesan, aquéllas por las que nos sentimos más concernidos, aquéllas en las que nos queremos centrar.

Volvamos, entonces, a Twin Peaks. Y una pregunta se impone de entrada. ¿Por qué marcar aquí el inicio de nuestro trayecto? Pues porque la serie creada a principios de los noventa (19901991) por Mark Frost y David Lynch constituye en sí misma un muestrario de síntomas acerca de las transformaciones que comenzaban a tener lugar, al tiempo que nos ofrece un completo catálogo con las bases de lo que estaba por venir.

Hagamos un poco de memoria. Twin Peaks era una pequeña localidad imaginaria situada en una región montañosa y boscosa en los confines de Canadá (el rodaje se localizó en el estado de Washington). Pero, como bien señaló Thierry Jousse ${ }^{4}$, más que un decorado, la pequeña ciudad es un verdadero personaje de la serie, del mismo modo que más tarde lo serán en otras ficciones Cicely, Everwood, New Jersey, Baltimore, New Orleans, Atlantic City o la sureña Bon Temps en Louisiana (por poner algunos ejemplos pertenecientes a series que citaremos). No digamos ya la isla frente a la que se estrella el vuelo 815 de Oceanic Airlines en línea de Sidney a Los Ángeles.

¿Y qué se nos planteaba como punto de partida en Twin Peaks? Pues, entre otras cosas, y recogiendo el argumento apuntado en su día por José Avello Flórez ${ }^{5}$, una inversión del cuento de "Caperucita Roja": quiere esto decir que aquí ya se obvia la finalidad moral del cuento, aquélla destinada a advertir a la niña (a las niñas) que, si transgredían -aunque fuese inocentemente- las severas instrucciones morales recibidas sobre su conducta (en especial, no detenerse a hablar con ningún desconocido), el castigo sería brutal (y no vamos a entrar ya en las connotaciones psicoanalíticas del cuento ${ }^{6}$ ). Se obvia, pues, aquella finalidad, se omiten aquellas advertencias morales por periclitadas y redundantes. Aquí, lo primero que vemos es "a la niña díscola en el vientre del lobo, envuelta en un plástico, asesinada"7. Y esa imagen de Caperucita/Laura Palmer en la bolsa de plástico quedará fijada en el imaginario colectivo de los años noventa (Fig. 3).

De manera que las tradicionales normas morales basadas en sólidas creencias y los valores de ellas derivadas quedan desalojadas:

al revés de los relatos tradicionales, permanecen en segundo lugar, para dirigir toda la atención a una sola cuestión de la que derivarán todas las demás: ¿qué le ocurrió a Caperucita Palmer en el bosque? ${ }^{8}$

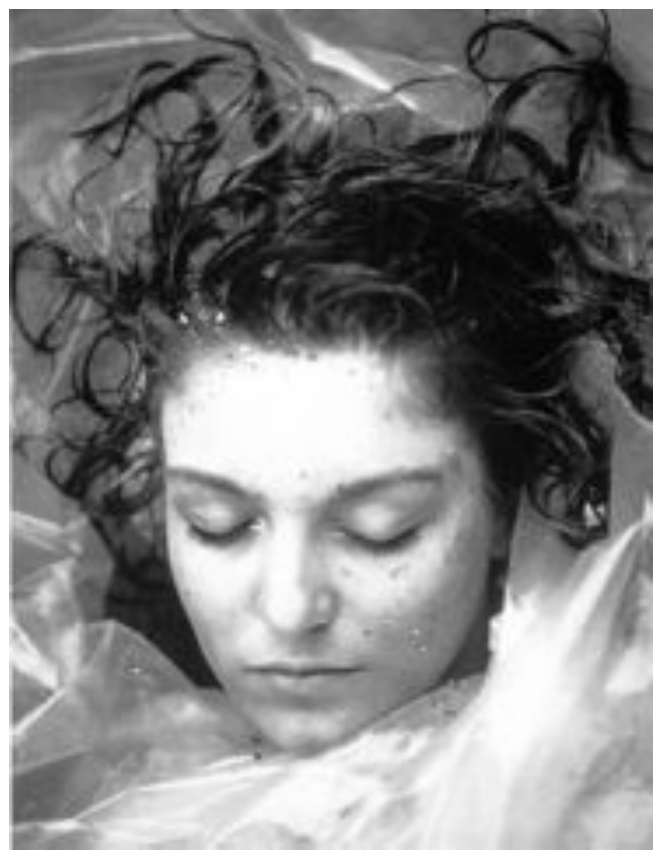

Fig. 3: Laura Palmer. Twin Peaks, episodio Piloto. 
Cabe preguntarse por los motivos de esa inversión. Afortunadamente, a estas alturas ya no resulta necesario remitirnos a Marc Ferro o Robert Rosenstone (entre otros) para tener claro que toda ficción audiovisual es susceptible de una lectura histórico-política o, de otra manera: podemos leer cada texto audiovisual (y no sólo las películas) como una transparencia superpuesta sobre un fondo socio-cultural más o menos borroso del que, sin embargo, nos revela elementos significativos (sea de forma directamente testimonial, sea vehiculando procesos de metaforización).

$Y$, ¿en que universo socio-cultural se inserta Twin Peaks? ¿de qué zeitgeist constituye reflejo? Pues de aquel que ya ha dado por abolidas las leyes del cartesianismo, de la lógica, de la razón ilustrada; los grandes relatos y héroes; los antiguos principios de previsibilidad que pretendían fijar el sentido de la vida (aunque, en realidad, la vida no tenga nada que ver con eso). Aquel, entonces, que ha dejado atrás el espíritu sociocultural y moral del antiguo régimen en un mundo que se ha hecho tremendamente complejo, un mundo que es difícil de seguir, de vivir y comprender (a no ser que, como escribió Eduardo Haro Tecglen, uno haya hecho ya la reconversión necesaria para aceptar que comprender es aceptar no-comprender: como es la vida misma). Aquel universo sociocultural, en definitiva, que conocemos como posmodernidad.

En consecuencia, si el universo cultural se hace más complejo, los relatos tendrán que hacerse más complejos. Y Twin Peaks constituye la primera gran 'transparencia' serial y televisiva que se superpone a ese universo, y lo hará en un momento, además, en el que un significativo porcentaje de la audiencia, cansado de la linealidad y previsibilidad predominantes en las ficciones televisivas, reclamaba eso. De hecho, uno de sus creadores, Mark Frost, ya se había encargado de ponerlo de manifiesto a lo largo de los años anteriores a través de su reputado trabajo como guionista de una de las más grandes e innovadoras series de la década de los ochenta, Hill Street Blues/Canción triste de Hill Street, NBC: 1981-1987.

David Lynch, pues, se encuentra con Mark Frost y ambos, gracias a sus respectivos presti- gios en aquel entonces (el cineasta había enlazado varios títulos de referencia en el cine de aqueIlos años como El hombre elefante [The Elephant Man, 1980], Terciopelo azul [Blue Velvet, 1986] o Corazón salvaje [Wild at Heart, 1990]), crean para la $A B C$ una propuesta fuera de toda norma trenzando una hábil -y sólo aparente- síntesis entre algunos géneros codificados, como eran la soap opera televisiva (esto es, el folletín) y la investigación criminal/encuesta policial, con una concepción autoral y una retórica artística a través de las cuales Frost y Lynch trazarán una escritura abiertamente deconstructiva. Por una parte, porque en Twin Peaks el tradicional folletín melodramático familiar devendrá, entre otras cosas, en una mórbida exploración de los vericuetos psíquicos que se ocultan tras la institución familiar; una institución que, a lo largo de los años siguientes y como es sabido, va a ser puesta en solfa en numerosas series televisivas a través de diversos registros ${ }^{9}$ : a una sociedad disfuncional corresponderá una familia disfuncional (disfuncional -entiéndase- desde los preceptos tradicionales y canónicos, ya que no por eso la familia va dejar de ocupar un lugar buscado, o su disgregación va a dejar de ser un motivo de temor).

Por otro lado, porque esa investigación, esa encuesta policial va a dejar muy atrás ya los códigos habituales y decimonónicos de este tipo de relatos. Cabe recordar en este sentido que la premisa argumental de la investigación del asesinato de la adolescente Laura Palmer había sido concebida en buena medida como banderín de enganche cara al público (al menos, en eso confiaban los directivos de la $A B C$ que dieron inicialmente luz verde al proyecto), y en buena medida así funcionó, al menos durante la primera temporada. Pero ahora ya no encontraremos a un Sherlock Holmes, a un Poirot ou a un Maigret que apliquen su lógica victoriana a un mundo más o menos estable, con costumbres sólidas, con valores fijos y establecidos, con una escala estamental en la que los individuos (sus actitudes, comportamientos, iniciativas) responden a lo que cabe esperar de su correspondiente grupo social. Un mundo en el cual cualquier transgresión de los hábitos, las costumbres y los valores puede ser detectada y descubierta, desentrañada, a través de la observación, el estudio 
y la lógica (es decir, la ciencia). Ni siquiera encontraremos a un Sam Spade, a un Philip Marlowe o a un Lew Archer quienes, a pesar de moverse ya en otro tipo de sociedad (e incluso de involucrarse físicamente en la sucesiva comprobación de sus hipótesis), seguían operando a partir de la misma lógica analítica, inductiva, de sus predecesores, bien que incorporándola

a un método científico típicamente americano: el behaviorismo pragmático; observan las conductas y proceden por ensayo $y$ error, como los buenos positivistas, con la peculiaridad de que siempre son ellos los conejillos de indias que verifican personalmente cada paso de la hipótesis, recibiendo los consecuentes golpes, a partir de los cuales aclaran el caso ${ }^{10}$.

Nada de esto habrá aquí. Porque el mundo sobre el que operaban aquellos detectives ya no existe. Era el mundo, como recordaba Enric González, anterior a Auschwitz, a la bomba atómica, a la física cuántica y a los derivados financieros. Pero los relatos, este tipo de relatos, seguían en buena medida anclados en ese mundo, como si quisiésemos seguir fijados a él, a aquel mundo de certidumbres del siglo XIX ${ }^{11}$. Es difícil, desde luego, vivir sin las antiguas referencias, resulta incómodo transitar sin la antigua orientación, haber perdido las claves del sentido (y sobre esto, sobre esta carencia, también se fundarán muchas de las series de esta última década). Es más, nos resistimos a hacerlo. Quizás por eso, transcurridos más de veinte años, dos de las series más vistas del mundo sean House y C.S.I. (esta última, en sus diversas clonaciones), en las que la enfermedad, el crimen, el caos, pueden ser domados, pueden todavía resolverse mediante la mente científica.

Pero Frost y Lynch no jugaron a eso. Ellos van a asumir esa pérdida de las bases, ese trance de lo sólido a lo líquido (y al final de este texto volveremos sobre esta cuestión) que caracteriza al nuevo universo socio-cultural, en el que todo se ha vuelto un complejo sistema de apariencias, de máscaras y en el que, como en la vida misma, entra en juego lo irracional. De manera que de nada valen los antiguos detectives, porque ni el mundo ni sus habitantes son los mismos y, por lo tanto, sus iniciativas, actitudes y comportamientos no tienen porqué responder a los que tradicionalmente (razonablemente?) cabría esperar de ellos. Y para enfrentarse a todo esto ponen en escena a un otro tipo de detective, al peculiar agente del FBI Dale Cooper (Fig. 4), un tipo sometido al principio de indeterminación (puesto que, a diferencia de lo que ocurría en el relato clásico, ahora ya no va a ser el guía del acceso al saber para el espectador sino, en todo caso, nuestro representante en la ficción), en quien transitan forzosamente -como bien apuntaba

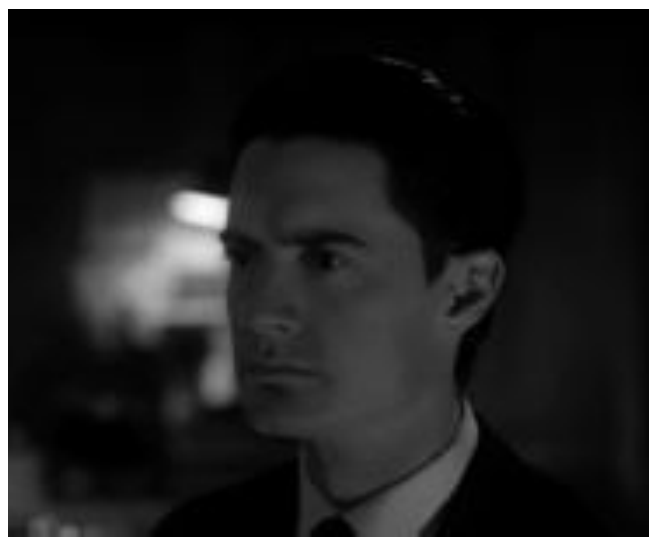

Fig. 4: El agente Cooper (Kyle MacLachlan).

Thierry Jousse- los significados más esotéricos y las intrigas más retorcidas ${ }^{12}$, que tendrá que enfrentar esa lógica circular y tremendamente compleja de un mundo nuevo con otras armas, tales como el budismo tibetano y la intepretación de los sueños y otras señales:

El nuevo investigador ya no es un científico teórico, como Holmes, ni un científico pragmático, como Spade, Marlowe o Archer, sino algo mucho más complejo: es un poeta o un mago, que confiere la misma importancia a un sueño que a una huella dactilar y que, sin embargo, maneja la estadistica y ha estudiado a fondo las técnicas de sus predecesores [...] Su episteme ya no es el análisis y la clasificación, sino la analogía y el contacto ${ }^{13}$.

Ya lo dejó escrito Santos Zunzunegui: 
[Cooper] es aquel cuyo conocimiento no racional, cuyo contacto intuitivo con la realidad será capaz de caer en la cuenta tanto del carácter doble de la misma-ejemplificado en el personaje de la prima de Laura Palmercomo de que sólo la toma en consideración del revés de las cosas -ese sueño en el que un lenguaje vuelto como un guante sobre si mismo autoriza la enunciación de la verdadpermite un acceso directo a la auténtica sustancia de las cosas ${ }^{14}$.

Y, por supuesto, ese carácter doble de la realidad, ese revés de las cosas, dará cabida a lo paranormal, al misterio, al melodrama, al erotismo, al humor absurdo, a la angustia y -claro- a la locura:

En Twin Peaks sucede lo que en las novelas de Dostoiewski: que casi todos los personajes están locos (...) Y sucede que, como en las novelas de Dostoiewski, las señales de esas locuras no son evidentes desde el principio ni se manifiestan todas a la vez ${ }^{15}$.

\section{Oposiciones.}

Así pues, Frost y Lynch emprendían en el medio televisivo el trabajo de lo irracional. $Y$ en la escritura de lo irracional no cabe lo lineal, no cabe el simple argumento, de ahí la dificultad de la paráfrasis, la práctica imposibilidad -al contrario que con los relatos tradicionales- de transmitir oralmente a una persona que no haya visto la serie la información sobre lo narrado: porque aquí no habrá una serie de acontecimientos ligados por una lógica que les confiere sentido; aquí habrá un universo complejo, con códigos propios y plurales, en el que conviven diversas lógicas (o esa lógica circular a la que aludíamos) e interconexiones. Un no-relato en el que, al fin y al cabo, el cómo se cuenta era mucho más importante que el qué: "un relato coral que pretendía formular más preguntas al espectador que responderlas $^{\prime \prime 16}$. Y esto -hoy ya lo sabemos- devendrá un concepto muy importante, muy influyente, en la ficción televisiva contemporánea.

Porque lo que se planteaba en Twin Peaks es que, a lo mejor, la verdad, la auténtica sustancia de las cosas, estaba en esa Red Room (Fig. 5), en

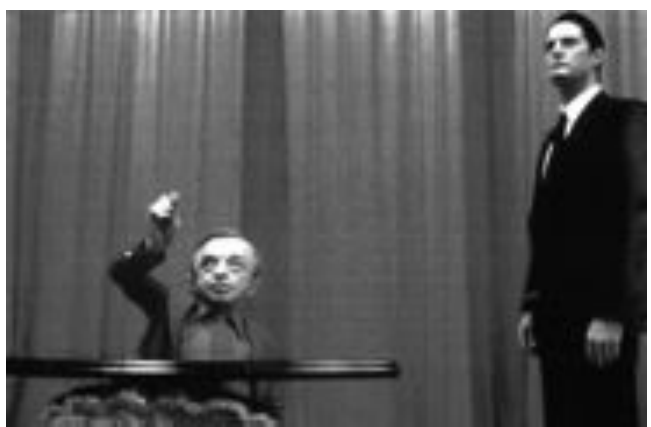

Fig. 5: Twin Peaks. La Red Room.

ese lugar onírico al que Cooper consigue acceder -y en cuyo interior logrará ver a Laura Palmer finalmente-, regido por ese enano a la vez familiar e inquietante; el mismo enano, por otra parte (interpretado por idéntico actor, Michael J. Anderson), que reaparecerá trece años después en Carnivàle (HBO, 2003-2004; Daniel Knauf) reencarnado en el personaje de Samsom, el director de la caravana, el único que tiene acceso a una nueva red room, en este caso ese carromato donde mora el poder (uno de los poderes), el conocedor/detentador de la verdad (Fig. 6).

Ya no nos puede extrañar, entonces, que ese neorrelato carezca de un final propiamente dicho y caiga progresivamente en el delirio, se disipe en la locura, se suspenda: How is Annie /

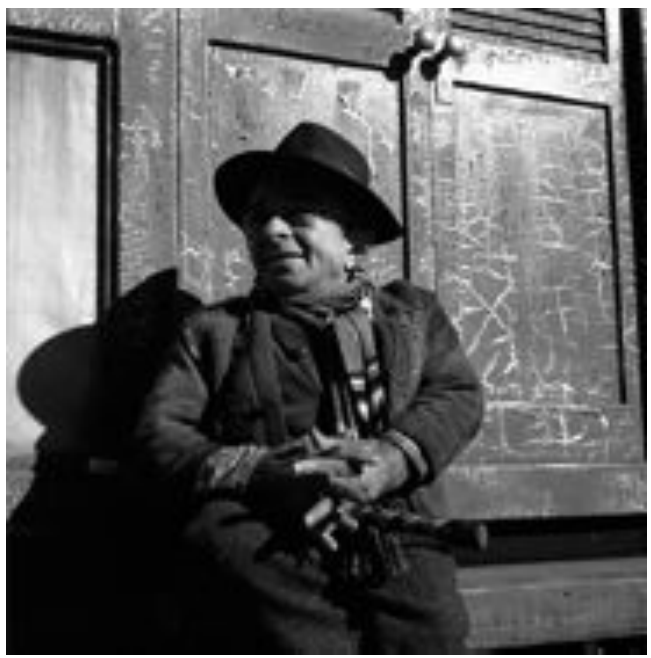

Fig. 6: Carnivàle. Samson (Michael J. Anderson), delante del carromato al que sólo él tiene acceso. 


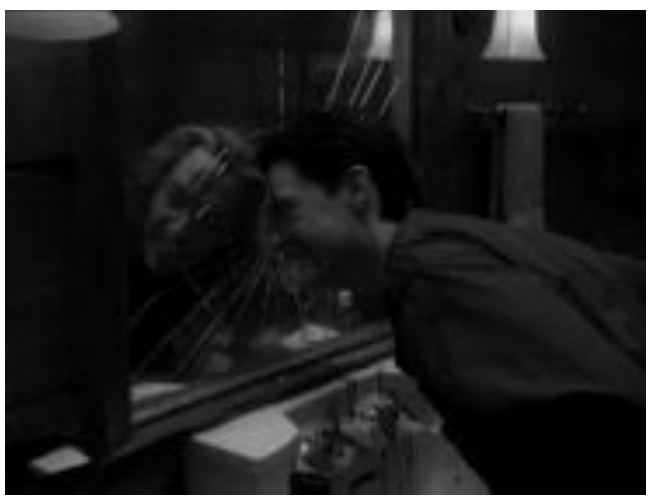

Fig. 7: Twin Peaks, episodio 22.

¿Cómo está Annie?... (Fig. 7). Cooper finalmente poseído por Bob, por esa verdadera encarnación del mal que antes poseyera a Leland Palmer, el padre de Laura, devenido ahora en doppe/gänger malvado al otro lado del espejo. ¿Cómo está Annie? Esa frase llena de maldad y locura que nos da a entender que el círculo del mal no se cerrará nunca (como tampoco se cerrará el círculo del relato).

Todo lo cual se ha puesto en escena con una nueva estética, estilizada y muy elaborada, y con una nueva sonoridad, empezando por esa ya mítica música compuesta por Angelo Baladamenti, un score mórbido y melancólico que contrasta con todo lo que se va cociendo en la pequeña comunidad y que potencia esa cadencia especial, psicotrópica, opiácea de la serie, una cadencia inusitada en la televisión estadounidense. $Y$ es que de televisión hablamos, puesto que ninguna de estas estrategias, así como mucho de las temáticas, era nuevo en el cine de David Lynch ${ }^{17}$. De hecho, gran parte de lo aquí comentado (desde el concepto temático, pasando por la configuración de relato y personajes, hasta el contraste música-imágenes) había sido ya explorado por el cineasta en un filme como Blue Velvet / Terciopelo azul (1985), un trabajo tremendamente radical por cuanto tenía de pulverización de la tan traída y llevada escisión del imaginario estadounidense, ese conflicto entre la idea transcendentalista y "orgánica" de la vida según la cual es en la contemplación de la naturaleza, unida al conocimiento y confianza en uno mismo, donde el hombre podrá encontrar su verdadero camino ${ }^{18}$, y su confrontación con el modelo urbano metropolitano por ellos mismos propuesto. De otra manera, la oposición entre la identidad esencialista del asentamiento comunal (que, en el imaginario norteamericano, tiene su sede idealizada en la small town, la pequeña comunidad de ambiente campestre; o bien en los suburbios residenciales de las grandes ciudades, con sus casas con jardín, traslación del antiguo modelo del cottage, de la prairie house ${ }^{19}$ ) y el cosmopolitismo urbano. Una dualidad que se hará patente en el ámbito de la producción arquitectónica, artística y audiovisual incluso hasta nuestros días. Podemos pensar, por ejemplo, en el land art como propuesta artística que proponía un regreso a la naturaleza contraponiéndose a la vivencia urbana y consumista (o así la entendieron algunos) del pop art; pero también, en el campo cinematográfico, en las cosmogonías ficcionales de dos de los grandes géneros clásicos, como son el western y el cine negro, que constituirían perfecto reflejo, respectivamente, de las dos caras del mito americano, así como sus héroes: el western configuraría el gran sí del discurso estadounidense, el sueño de la pradera, el mito agrario, la pequeña comunidad, con sus héroes inicialmente épicos; mientras que el cine negro sería el gran no, el reverso, la pesadilla urbana, con su héroe trágico ${ }^{20}$. De hecho, podemos recordar otro ejemplo cinematográfico de hace pocos años que demuestra que esa confrontación sigue vigente: el estreno, en 2004, de dos filmes como The Terminal (La terminal, Steven Spielberg) y The Village (M. Night Shyamalan, cuyo título de distribución española fue El bosque), metáfora perfecta de esa cesura entre el cosmopolitismo laico de la América metropolitana y la añoranza comunitaria de la América profunda.

En definitiva, la perenne vuelta a la naturaleza (aunque sea temporal) como acto de redención, de recomienzo ${ }^{21}$, ha estado presente, pues, en las narraciones audiovisuales norteamericanas de todo tipo a lo largo de las décadas: ahí están el cine de Douglas Sirk o series televisivas ya alejadas en el tiempo como Green Acres $^{22}$ (CBS, 1965-1971: protagonizada por un abogado neoyorquino que se traslada a vivir a un área rural) para recordárnoslo. En este sentido, Blue Velvet o Twin Peaks se proponen en su mo- 
mento como relatos transgresores que exploran la otra cara de ese imaginario tradicional estadounidense, que se sumergen no sin ironía (todos recordamos la primera secuencia del filme y los idílicos créditos de la serie) en esas comunidades (debajo de esas comunidades, en la psique de sus pobladores) para mostrar la pérdida - ¿la inexistencia?- de esa presunta inocencia histórica. Porque ya no es tiempo de falsas mitologías.

\section{Derivas.}

Mucho se ha escrito, por lo demás, sobre el influjo de Twin Peaks en la ficción televisiva contemporánea, en la posibilidad de una cierta ficción. Se ha señalado, por ejemplo, su peso en la concepción de series tan importantes en la década de los noventa como Expediente $X$ (The X-Files, Fox TV, 1993-2002; creada por Chris Carter), en el sentido de articular la trama sobre un misterio, de incorporar elementos de corte sobrenatural y fantástico, de su elaborado trabajo de estilización e incluso de las apreciables dosis de humor absurdo; incluso algunos analistas llevaron esa influencia a otras reseñables series de género fantástico posteriores como Buffy, cazavampiros (Buffy, the Vampire Slayer, Warner Bros. TV, 1997-2001, creación de Joss Whedon) y FringelAl límite (WB, 2008-2010, a cargo de
J. J. Abrams, autor de series de referencia como Alias y, desde luego, Lost/Perdidos). En cualquier caso, creemos que ese sentido lynchiano de lo fantástico -así como su inherente melancolíaha encontrado un eco más profundo en ciertas ficciones seriales del canal HBO como la ya citada Carnivàle o la miniserie Angels in America (2003, Mike Nichols), adaptación de la obra teatral de Tony Kushner sobre los primeros años del SIDA en Estados Unidos, repleta de reminiscencias surreales (incluído un explícito homenaje a Cocteau) (Fig. 8) y sobrenaturales, dentro de una atmósfera oscura y milenarista.

Twin Peaks se proponía, en definitiva, mostrar una realidad compleja y la propia serie, como texto audiovisual, era un producto de dicha realidad. Una realidad en la que, a tenor de lo que hemos expuesto hasta aquí, ya habían perdido su sentido el gran sí o el gran no. Y esta es la veta conceptual que va a abrir a otras creaciones dentro de la televisión, y que tendría su casi inmediata continuidad en Picket Fences (CBS, 1992-1996), la primera serie propia de David E. Kelley (el creador de productos como Ally McBeal y El abogado), cuyo título hacía referencia a esas vallas de madera tan típicas de las pequeñas poblaciones norteamericanas. Picket Fences fue otra propuesta bastante insólita

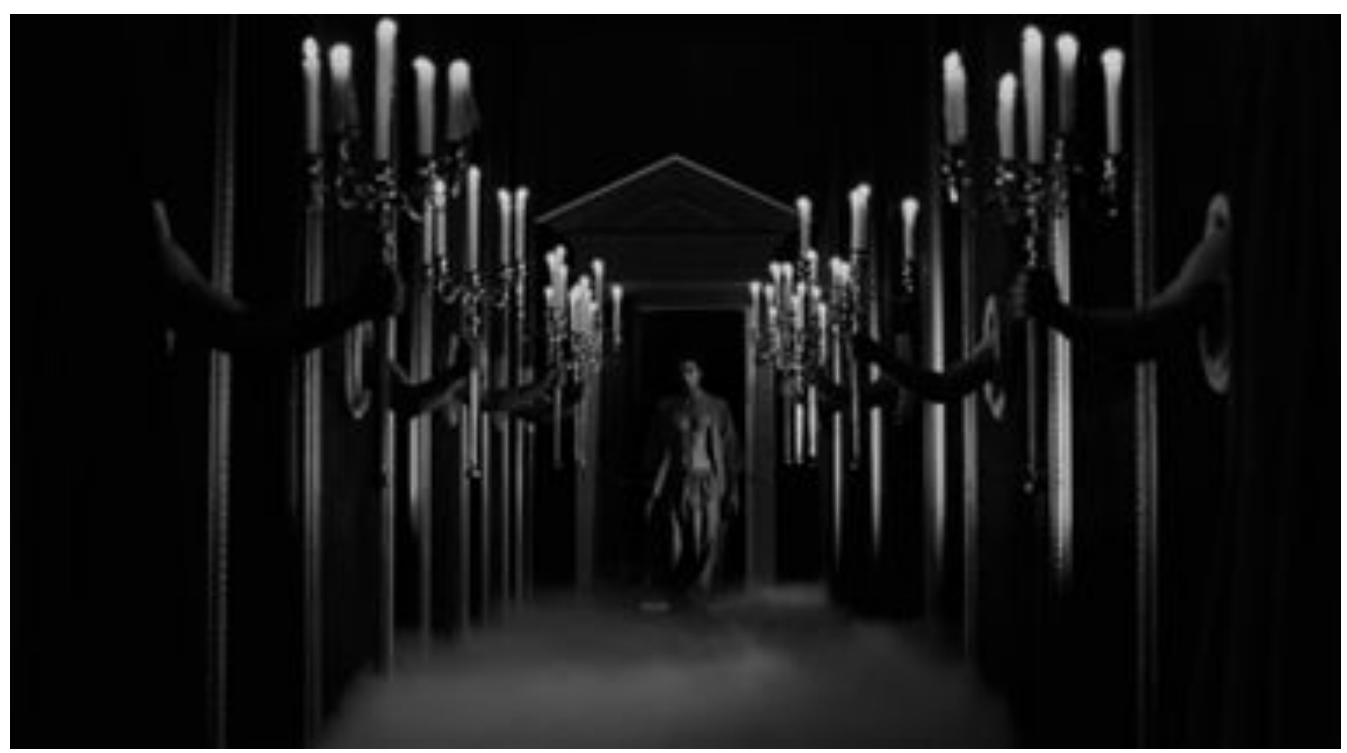

Fig. 8: Angels in America. Primera Parte: Millenium Aproaches/El milenio se acerca. 
-algunos la calificaron como "drama raro"- que ubicaba su historia en otra pequeña localidad, Roma (en Wisconsin), y articulaba otro peculiar microcosmos en el que, además de que una latente (cuando menos) locura estaba también bastante extendida, tenían cabida temas como la familia, el aborto, la homosexualidad, la creencia en Dios, la ética médica o los derechos constitucionales. Todo ello en medio de una trama en la que también aparecen la combustión espontánea humana, la existencia de vacas utilizadas para gestar y dar a luz bebés humanos, o el hecho bastante sospechoso de que una apreciable cantidad de habitantes de Roma mueren congelados $^{23}$. A partir de aquí, esa veta que hurga en el mito de la comunidad, o de ese otro tipo de comunidad que constituye el suburbio residencial (así como en algunos de sus pilares esenciales, caso de la familia -y ya hemos aludido a esto), va a seguir siendo excavada en los años siguientes, y de ella surgirán materiales dispares y memorables [v. n. 9].

Pero debemos señalar que no por ello esa escisión del imaginario americano se iba a extinguir. En todo caso, se iba a reformular. Sin duda, el ejemplo más claro en este sentido es el que nos ofrece una serie de culto como Doctor en Alaska (Northern Exposure, CBS, 1990-1995; creada por Joshua Brand y John Falsey), que nos presenta una idílica comunidad rural de Alaska, Cicely, en la que la indígena y autóctona población local convive en paz y armonía con todo tipo de auto-desterrados urbanitas (desde un exitoso broker hasta un ex presidiario filósofo, pasando por un astronauta) que han encontrado en ella el paraíso perdido, el lugar donde recomenzar, donde reinventarse, donde redimirse. $Y$, como contrapunto cómico-dramático, el judío y ultra-neoyorquino (según el tópico) doctor Joel Fleischman. Cicely es, en definitiva, todo aquello que los estadounidenses querrían ser y no son. De hecho, la latencia emersoniana seguirá ahí: no en vano, llegada la sexta y última temporada, el doctor Fleischman se retirará al poblado Manonash tras su fracaso amoroso con Maggie. Se perderá en la espesura, a la búsqueda de sí mismo. Pero, así y todo, la huella de Twin Peaks se dejará notar en algunos aspectos, como la omnipresencia de lo surreal, de lo fantástico, así como la asunción en la normalidad de una cierta locura generalizada. $Y$ hay también un continuo juego posmoderno de citas y homenajes, de reescritura de hechos históricos. Y hay más cosas, algunas de ellas muy comentadas años después, como los juegos temporales, que trabajan sobre una descomposición literal del tiempo ${ }^{24}$, o las realidades alternativas. ${ }^{25}$

También, casi 40 años después de Green Acres, otro reputado profesional urbano, en este caso un famoso cirujano llamado Andy Brown, decide mudarse con sus hijos a otra pequeña comunidad para así comenzar una nueva vida, que pasa por su refundación como padre de unos vástagos de los que lleva tiempo desconectado. El lugar se llama Everwood (WB, 2002-2006) y aquí el 'Fleischman' del asunto, el urbanita recalcitrante, estará personificado por el adolescente hijo de Andy, Ephram. Todo irá saliendo bien, pese a las dificultades. Andy tendrá que enfrentarse a una nueva vida como médico de medicina general y a sus hijos, además de a la ojeriza del doctor Abbott, el médico del pueblo, hombre conservador y receloso ante la llegada del eminente urbanita, al que dispensa un trato desagradable. Pero sólo aparentemente conservador, receloso y borde, como se demuestra en el capítulo 21 de la $1^{\text {a }}$ temporada, Una difícil decisión, cuando se aborda el tema del aborto. Y es que, entrando en el nuevo milenio y por muy familiar que se pretenda la serie (Warner Bros. TV es una mini-network ${ }^{26}$ ), y por mucha pequeña comunidad de la que se trate, hay conflictos reales que deben ser abordados. Picket Fences puede estar ahí detrás (incluida la estructura de drama familiar) pero sin sus dosis de locura.

Algo parecido podríamos decir de otra serie de la misma cadena, Las chicas Gilmore (Gilmore Girls, 2000-2007), otro show dramático familiar (aquí una joven madre, Lorelai, los padres de ésta y su brillante hija Rory), que se desarrolla en una pequeña comunidad, la ficticia Stars Holow, en Connecticut (algunos de cuyos personajes deben mucho a Doctor en Alaska), presentada como un arquetipo ideal de lo que sería Nueva Inglaterra, y que busca en la agilidad y agudeza de sus diálogos - a la manera de la comedia clásica americana- su mejor baza.

En cualquier caso, ni en Cicely, ni en Everwood, ni en Stars Hollow, aparecen orejas en los 
jardines, adolescentes en bolsas de plástico ni conciudadanos congelados.

Twin Peaks, en fin, significó también el paso de una serie televisiva a la condición de objeto artístico digno de estudio académico. Suele citarse el número monográfico que la prestigiosa revista Literature / Film Quaterly dedicó a la serie en 1993. Pero no era la primera. Ya desde la emisión de su primera temporada, Twin Peaks llamó la atención de las más prestigiosas revistas cinematográficas de todo el mundo. $Y$ es que David Lynch era un cineasta. $Y$ un cineasta de prestigio autoral. Lo cual, a su vez, nos introduce en un tema cada vez más complejo (y es que todo se hace cada vez más complejo, así empezábamos), el de las relaciones cine-televisión.

\section{Traslados.}

Evidentemente, Lynch no era el primer cineasta que se acercaba al medio televisivo, pero sí que lo hizo todavía como lo habían hecho anteriores cineastas de prestigio: como una experiencia, una oportunidad de ensayar cosas, de escribir sobre un nuevo soporte en el que reverberaba su discurso fílmico (si bien también hay que señalar que intentó prolongar, infructuosamente, esta relación). Como, sin necesidad de retrotraernos ya a las experiencias de, por ejemplo, Hitchcock en los Estados Unidos, o Bergman y Rossellini en Europa, desarrollaron, a partir de los años 80, R. W. Fassbinder (Berlin Alexanderplatz, 1980), K. Kieslowski (El decálogo, 19891990), Lars von Trier (Kingdom, 1994) o, apurando el argumento, Marco Tulio Giordana ( $L a$ mejor juventud, 2003). Pero todas ellas fueron series concebidas como proyectos cerrados en sí mismos. Sin embargo, en los últimos años esa tendencia ha cambiado: aunque siga habiendo casos de cineastas-estrella que se acerquen a la televisión (a sus series favoritas) para, de vez en cuando, contribuir con un episodio especial a las mismas (caso de Quentin Tarantino con el celebérrimo episodio doble Grave Danger / Peligro sepulcral, que cerró la quinta temporada de CSI Las Vegas), o bien prolongar en este medio algunas de las líneas temáticas de su cine (casos de Steven Spielberg -asociado con Tom Hanks- con la producción de sus series Band of Brothers/Hermanos de sangre [2001] y The Paci- fic [2010], que venían a completar una trilogía iniciada en formato cinematográfico con Salvar al soldado Ryan [Saving Private Ryan, 1998]; de Martin Scorsese como productor ejecutivo -y realizador del primer episodio- de Boardwalk Empire, un nuevo acercamiento al mundo de la mafia, esta vez desde una perspectiva histórica y situándonos en Atlantic City; o de Todd Haynes, quien con Mildred Pierce [2001], adaptación de la novela homónima de James M. Cain, prolongaba la exploración del melodrama doméstico que había llevado a cabo en Lejos del cielo [Far from Heaven, 2002] [27), lo cierto es que en muchos casos un gran conjunto de directores (Jim McBride, Rodrigo García, Mike Figgis, Brian Singer, Mario Van Pebbles, Frank Darabont, Barbet Schroeder, entre muchos otros que se podrían citar $\left.{ }^{28}\right)$ comienzan a frecuentar la dirección televisiva gracias al terreno abonado que les están ofreciendo productores-guionistas como Aaron Sorkin, Allan Ball, J. J. Abrams, David Chase, David E. Kelley, Steven Boccho, Mathew Weiner o David Milch, por citar algunos nombres conocidos entre nosotros (un caso especial que nos viene a la mente es el del trabajo que acostumbra a desenvolver la cineasta Agnieszka Holland para las series de David Simon; o también el que desarrolla Walter Hill a la hora de poner las bases de otra gran serie, Deadwood).

Hablamos de productores-guionistas. $Y$ es que la ficción televisiva contemporánea introduce una alternativa respecto al cine (ya que, como escribió David Simon, "en la televisión por entregas, al tratarse de historias continuadas, es el guionista quien tiene succión"29) que incluso afecta al tradicional concepto de autoría. La autoría corresponde ahora al creador de la serie: ahora ya no se trata de "a film by/ una película de..." sino de "created by/una serie creada por..." Como pertinentemente señalaba Carlos Reviriego,

Existe el autor televisivo, y esto sí es una novedad. Un autor ciertamente singular si tenemos en cuenta que no genera sus imágenes porque no dirige los capítulos de la serie (si acaso, el piloto y los capítulos estrella), ni tampoco escribe todos los guiones (sólo algunos) [...] ¿Qué es el creador entonces? ¿Cuál es su cometido? En la entrevista que 
le realizó Cahiers du Cinéma a David Chase, el artífice de Los Soprano explicaba que la función más importante del "creador" consiste en dotar a la serie de una unidad de visión. "Consistency in voice and style", decía a modo de consigna ${ }^{30}$.

Lo curioso es que una gran parte de los nombres citados (y otros que podríamos añadir, como el de Jerry Bruckheimer) corresponden a guionistas (generalmente, aunque también algunos productores) provenientes del cine. Gente que ha llegado al medio buscando (o atraídos por) un hábitat en el que poder abordar unas temáticas y hacerlo de un modo tal que sería imposible en la gran industria cinematográfica pero también, en la mayor parte de los casos, en la tv tradicional. En realidad, ya lo reflejó desde un principio el eslogan de HBO (Home Box Office), el primer canal estadounidense por cable (y, por tanto, libre de censura) de alcance nacional : "It's Not TV. It's HBO". Y, efectivamente, HBO era otra cosa: para empezar, íntimamente vinculada a la industria cinematográfica desde sus orígenes (asociada a Columbia Pictures y CBS, había fundado en 1982 una compañía para la producción y distribución de películas, Tri-Star). Surge aquí otra cuestión: cabe preguntarse si, a día de hoy, sigue teniendo sentido seguir hablando de cine y televisión como de territorios distintos cuando lo cierto es que en la actual esfera del audiovisual no son sino ramas que muchas veces pertenecen a las mismas corporaciones, a los mismos conglomerados empresariales, como resultado de un proceso que ya comenzó a mediados de la década de los 70.

Pero es que esa confluencia no sólo es industrial, ya que muchas de las estructuras narrativas y de los recursos lingüísticos que a lo largo de la última década y media vienen proponiéndose desde la ficción televisiva son de origen cinematográfico (el mismo de sus hacedores, como señalábamos hace un momento), aprovechando ahora, eso sí, las ventajas del formato serial (1315 horas por temporada) frente al cinematográfico (2-3 horas como máximo) para desarrollar historia, situaciones y personajes ${ }^{31}$. Hay además series en las que esa filiación cinematográfica se hace muy evidente de manera consciente como en el caso de Los Soprano (The Sopranos; HBO,
1999-2007), tanto a nivel estructural (en el sentido de que David Chase concibió cada uno de los capítulos como una película) como referencial: la vieja guardia -la de Tony Soprano- tiene su referencia sobre todo en las dos primeras entregas de El Padrino (F. F. Coppola), mientras que para la generación de su sobrino Christopher las referencias están en Martin Scorsese (especialmente el Scorsese de Casino) o Quentin Tarantino; referencias que tendrán directa consecuencia en su manera de entender la Mafia y sus comportamientos, en lo que constituye a lo largo de la serie un riquísimo juego intertextual. Quizás, efectivamente estemos ya en el hipercine del que hablan Lipovetsky y Serroy ${ }^{32}$, en el que una buena parte de los seriéfilos está constituida por cinéfilos ${ }^{33}$.

Pero que no se nos malinterprete. Nada de todo esto hará de las series meros productos seguidistas de esas caligrafías cinematográficas, antes bien, configurarán a partir de ahí unas formas y lenguaje propios. Baste pensar en el proceso de reescritura que está teniendo lugar con los géneros. Pongamos dos ejemplos: 1) Frente a la banalización -o, en palabras de Jordi Costa, emasculación- del mito vampírico, convertido en material pseudorromántico para (pre)adolescentes en una saga cinematográfica como Crepúsculo, el gótico sureño, la inmersión oscura, arrebatada, hiperrealista, ritual y sexual en el relato de vampiros y otras criaturas que propone Alan Ball ${ }^{34}$ en su última creación, True Blood (HBO, en emisión desde 2008). 2) Frente al mito del héroe épico de aquel western clásico, del centauro del desierto y de las grandes praderas, de ese héroe que contribuirá a fundar la comunidad antes de volver a su territorio y tiempo míticos (el simbólico plano general final), los personajes trágicos, la claustrofobia, la penumbra, la suciedad de Deadwood (HBO, 2004-2006), esto es, la voluntad de David Milch por dotar de realismo a su creación, a su lugar, a sus personajes, a su lenguaje, a sus situaciones ${ }^{35}$, construyendo así una nueva revisión del pasado (que se viene a unir a las cinematográficas), una reescritura radical de la gran constante del género: la fundación del orden a partir del caos.

$Y$ es que en ciertas ficciones televisivas del nuevo milenio el realismo es importante, la cons- 
trucción de lo cotidiano es importante. Se está articulando algo en lo que todas las piezas tienen importancia, como declara en un momento dado el detective Lester Freamon en The Wire (HBO, 2002-2008; David Simon). Aunque no sepamos, por ejemplo, que el actor Wendell Pierce, el inolvidable detective "Bunk" Morehead (Fig. 9) en la misma serie, está encarnándose en cierto modo a sí mismo como el músico Antoine Batiste (Fig. 10) y relatando su historia y la de su ciudad en Tremé (HBO, desde 2010; David Simon y Eric Overmyer) , ya que él, su familia, fueron algunos de los cientos de miles de afectados por el paso del huracán Katrina por Nueva Orleans, como recogió Spike Lee en su serie documental When the Leeves Broke (2006; una producción de... HBO Documentary Films (Fig. 11): las imágenes, pues, se interrelacionan, se vinculan) ${ }^{36}$.

\section{Desolaciones y disoluciones.}

La complejidad. Rematada la posmodernidad y en plena travesía de la hipermodernidad post 11-S, nos encontramos con la pérdida de sentido, de las referencias; nos encontramos en la modernidad líquida definida en sus tesis por Zygmunt Bauman, ese estado en el que las antiguas dualidades definidas por el marco de la anterior modernidad han quedado anuladas. Un entorno fluido y muchas veces inasible, híbrido, fragmentario, en el que las personas/los personajes hacen cosas inesperadas, extrañas, impulsados por razones desconocidas. $Y$ hemos caminado mucho desde aquellos habitantes de Twin Peaks hasta los personajes desubicados de Lost/Perdidos, que tendrán que adaptarse y mutar continuamente en un entorno inseguro (el mismo entorno sublimado que el de nuestra inseguridad colectiva y global tras el 11-S), en el que hasta el tiempo lineal se descompone, si quieren sobrevivir. Señalaba muy acertadamente Anna Petrus cómo Lost extiende una red de tramas cuya estructura se asemeja a la forma en que Internet organiza y desorganiza, recuerda y olvida el exceso de información de nuestra sociedad $^{37}$. Una estructura en Red que, por cierto, encontró perfecto reflejo en su recepción y difusión, convirtiéndose, como todos sabemos, en un verdadero fenómeno intermedial de carácter altamente adictivo.

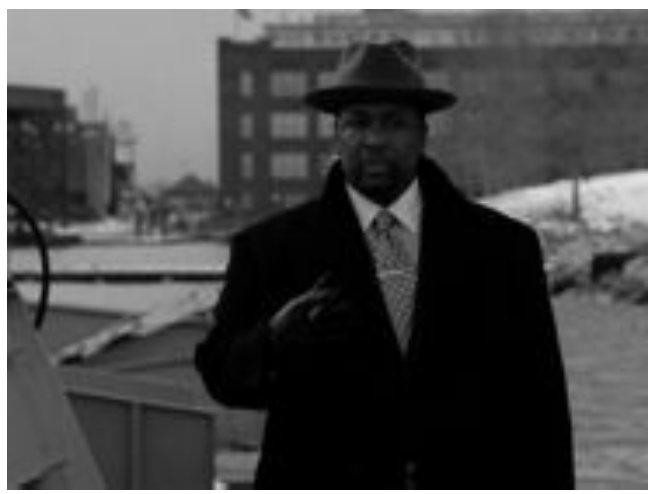

Fig. 9: 'Bunk' Morehead. The Wire/Bajo escucha.

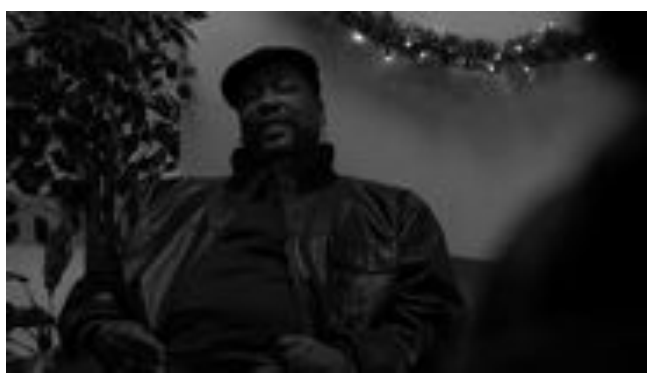

Fig. 10: Antoine Batiste. Tremé.

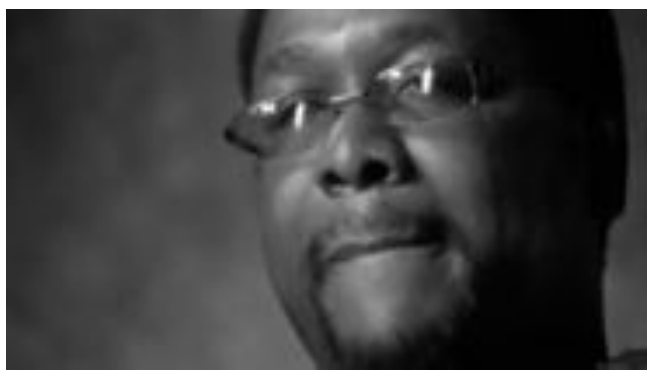

Fig. 11: Wendell Pierce ofreciendo su testimonio en When the Leeves Broke (Spike Lee, 2006).

Y en esta modernidad líquida en la que todo se diluye ${ }^{38}$ una serie de temas mayores van surgiendo. La perplejidad, la melancolía, la desolación, el cuestionamiento de la identidad son algunos de ellos (no resulta casual en este sentido -no puede serlo- la enorme frecuencia con la que muchos de los creadores de estas series introducen en las mismas elementos de inspiración autobiográfica). De nada valen ya, claro, los antiguos tópicos identitarios (a los que, por lo 
demás, muchas veces los personajes se ven/nos vemos enfrentados) como no sea para comentarlos socarronamente. Es lo que hacen relatos rompedores como Los Soprano, por ejemplo -la eterna lucha de Tony entre lo individual/familiar y lo comunitario, como bien estudió Peter Steeves ${ }^{39}$; o su "¿quién soy? ¿adónde voy?" cuando despierta del coma-, pero también interludios neoclásicos como la ya citada The Pacific ${ }^{40}$.

Ahora la identidad se encuentra fracturada, consiste siempre en interpretar ${ }^{41}$, lo cual conlleva un sentimiento individual de pérdida, tanto a nivel personal (pensemos en un personaje como Don Draper, el protagonista de Mad Men [AMC; creación de Matthew Weiner] quien, durante las primeras temporadas de la serie, se nos presenta como un hombre escindido entre un pasado fantasmático cuya sombra no cesa de proyectarse sobre él y un presente construido sobre una falsa identidad) como colectivo (sobre el que reflexiona la miniserie The Company [TNT, 2007], adaptación de la novela homónima de Robert Littel que versa sobre el espionaje y la Guerra Fría hasta la caída del muro de Berlín pero que al mismo tiempo se configura como una narración tremendamente melancólica sobre la pérdida: de la identidad, del amor, del sentido; de todo aquello que van perdiendo los personajes camino del vaciamiento absoluto, del mismo modo que el relato se va vaciando a medida que avanza hacia su desoladora secuencia final $)^{42}$.

En medio de todo esto, de un modo de vivir contemporáneo vaciado de dualidades y referencias (ya sean espirituales, políticas, éticas o morales), abocado al individualismo y a la soledad, a la inestabilidad; en medio de este presente posideológico y pospolítico, el capitalismo neoliberal ha tomado el mundo, incluso el mundo de centro-izquierda. En palabras de Slavoj Zizek, "[a los gobiernos de izquierda] el capitalismo les permite legalizar el aborto, las bodas homosexuales, asuntos de género. Nunca las reglas del mercado"43. ¿Qué hacer, entonces? Zizek apuesta por la militancia en una izquierda radical insobornable como única posibilidad de cambiar el curso de las cosas. ¿Pero es esto posible?

Según su creador David Simon, la segunda temporada de The Wire es un tratado sobre la muerte del trabajo y la traición a la clase obre- ra ejemplificada por el declive de los sindicatos portuarios de la ciudad de Baltimore. Esa temporada tendrá un héroe, Frank Sobotka (Fig. 12), que se enfrentará al sistema y sus corruptelas. Pero ese héroe americano ya no podrá ser épico y devendrá trágico, otro cadáver envuelto en una bolsa de plástico (Fig. 13). Otro personaje de Simon, otro héroe zizekiano, es el indignado Creighton Bernette (Fig. 14) de Tremé, quien, después de buscar durante meses "su" Nueva Orleans, después de luchar por todos los medios por la posibilidad de su restitución, enfrentándose a todo el sistema, no la encuentra. Sólo sus ecos, su fantasma. Hasta que él mismo, elemento constitutivo de aquella ciudad que ya no existe, opte también por desaparecer arrojándose por la borda de un barco (Fig. 15).

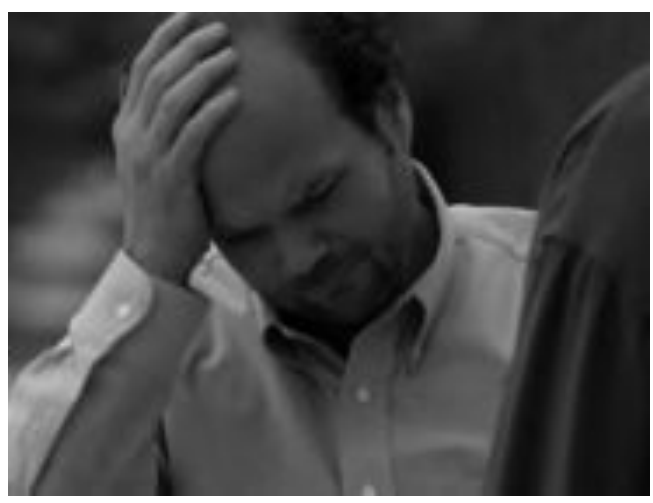

Fig. 12: Frank Sobotka (Chris Bauer). The Wire. Segunda temporada (2003).

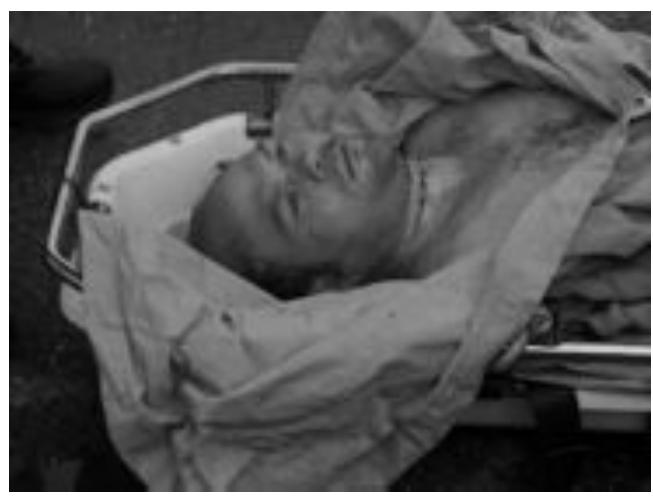

Fig. 13: The Wire. Segunda temporada, Episodio 9 (24): Bad Dreams. 


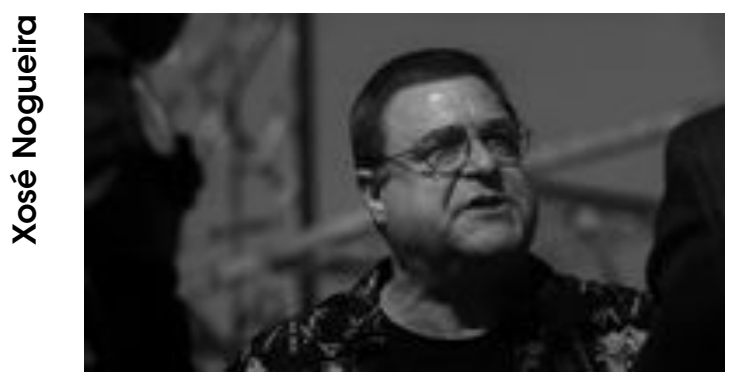

Fig. 14: Creighton Bernette (John Goodman), en el episodio 1 de Tremé: Do You Know What It Means?

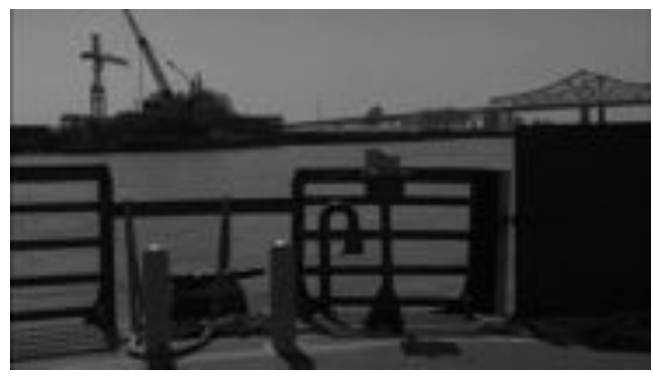

Fig. 15: Tremé. Primera temporada, episodio 9: Wish Someone Would Care.

Frank y Creigh no pueden/no quieren adaptarse a este mundo líquido, como sabían/querían hacerlo los personajes de Lost. En ellos, las problemáticas de política e identidad confluyen. Quien renuncia (aunque sea por convicciones ideológicas y/o morales) a la mutación, está condenado. Pero ellos no lo ven así. Para ellos, mutar significa en buena medida renunciar a la propia identidad, escindirla, morirse simbólicamente. La muerte o la muerte. Frank y Craigh no cesan de morirse ante sí mismos simbólicamente, derrota tras derrota, sabedores de su destino trágico, hasta que llega la muerte física.

Como llega la muerte del relato. Como hace tiempo que había llegado. Y volvemos a Twin Peaks: "El relato ha estallado, el universo narrativo se ha roto...", escribía Jesús González Requena a finales de los 90 a propósito de aquella serie ${ }^{44}$. El mundo se ha hecho demasiado complejo para la culminación unitaria y el clímax dramático de antaño. Frente a aquéllas, al relato sólo le queda ya su devenir rizomático (el existir, el rizoma que se extiende horizontalmente, la desterritorialización) frente a la anterior estructura arborescente (el ser, el lugar, el territorio), por echar mano de la terminología acuñada por Deleuze y Guattari ${ }^{45}$. Al final el relato queda inmóvil, se suspende, no podrá -no tendrá por qué- resolverse (recuérdese la tan discutida secuencia final de Los Soprano). A lo sumo, podrá auto-morirse, auto-enterrarse, como hizo Allan Ball en $A$ dos metros bajo tierra: tres episodios antes del final, Natan sufre un ataque y muere. Pero los destinos de la serie y del personaje estaban unidos: la ficción comenzaba con su regreso al hogar, donde se quedaba a vivir tras la muerte del padre. En palabras de Hervé Aubron: Desfigurado, sin órganos, el cadáver exhibido de Nate es también el de la serie, destinada a convertirse en una concha vacía (...) Lo conjurado por la muerte, la serie, se presenta asimismo como la propia muerte, vaguedad canibal girando en bucle ${ }^{46}$. De ahí la construcción de ese "clip-panteón" que clausura la serie, en cuyos tres minutos se entierra a todos los protagonistas, en un prolongado duelo exponencial que deja al espectador enfrentado a una pantalla despoblada, a una pantalla en blanco.

Seis años después, Vince Gilligan, el creador de otra serie contemporánea de culto, Breaking Bad (AMC, en emisión desde 2008), comentaba acerca del décimo episodio de la tercera temporada (Fly):

(...) una especie de Esperando a Godot. Estamos muy orgullosos del resultado, es un episodio en el que el relato casi desaparece $y$ en el que dedicamos un tiempo a explorar los personajes en ese preciso momento de su recorrido ${ }^{47}$.

Un nuevo paradigma. 


\section{NOTAS}

1 Surgida de nuestra conferencia en el Seminario organizado por la UIMP De "Los Simpsons" a "Perdidos". El boom de las teleseries. (Valencia, julio 2010) y posteriormente desarrollada en el marco del proyecto de I+D+i Narrativas cruzadas: hibridación, transmedia y performatividad en la era digital. Ref. FFI2012-35296, financiado por el Ministerio de Economía y Competitividad del Gobierno de España.

${ }^{2}$ A lo largo de mi carrera como periodista, siempre me dijeron que tenía que escribir pensando en el lector medio. El lector medio, tal y como ellos lo entendian, era un suscriptor blanco, acomodado, con-dos-hijos-coma$y$-algo y tres-coches-coma-y-algo, un perro y un gato, más los consabidos aparejos de jardín; una persona ignorante que necesita que se lo expliquen todo, ya mismo. Así, tu exposición se convierte en un peso increible, en un auténtico peñazo. Que le jodan. Pero que le jodan bien. "David Simon, entrevistado por Nick Hornby", en VV.AA.: The Wire. 10 dosis de la mejor serie de la televisión, Madrid, Errata naturae, 2010, p. 66

${ }^{3}$ C. Cascajosa, Prime Time. Las mejores series de TV americanas, Madrid, Calamar Ediciones, 2005, p. 16.

${ }^{4}$ Thierry Jouse, David Lynch, ParisMadrid, Cahiers du cinéma/El País, 2007-2008, p. 50.

${ }^{5}$ Cfr. J. Avello Flórez, "El relato de la complejidad", en Archivos de la Filmoteca, no 8 (dic. 1990 - feb. 1991), pp. 136-141.

${ }^{6}$ Expuestas en su día por Bruno Bettelheim en Psicoanálisis de los cuentos de hadas, Madrid, Crítica, 1992 (1 ${ }^{\text {a }}$ ed., 1977), pp. 235-257.

${ }^{7}$ Avello Flórez, Art. cit., p. 136

${ }^{8}$ Ibidem, pp. 136-137

9 Pensemos en series como Matrimonio con hijos, Weeds, Brothers and Sisters/Cinco hermanos, Big Love, A dos metros bajo tierra/Six Feet Under, Mujeres desesperadas/Desesperate Housewives, Modern Family o The Killing (versión norteamericana de la danesa Forbrydelsen), sin olvidar, por supuesto, Los Soprano, entre otros posibles títulos. También las series de animación han jugado un papel importante en este sentido a partir de la seminal Los Simpson (en emisión desde
1990); el ingenio del creador de la serie, Matt Groening, ha encontrado un adecuado continuador en el corrosivo Seth MacFarlane, a quien se deben $\mathrm{Pa}$ dre de familia y American dad.

${ }^{10}$ Avello Flórez, Art. cit., p. 140.

11 Cfr. E. González, "XIX", en EI País, 17-06-2009.

12 Op. cit., p. 53.

$13 \mathrm{~J}$. Avello Flórez, Art. cit., p. 140.

${ }^{14} \mathrm{~S}$. Zunzunegui, "De cerca y de lejos", en Archivos de la Filmoteca, n 8 (dic. 1990 - feb. 1991), p. 155.

15 Jesús González Requena, "La cadencia de la locura", en Archivos de la Filmoteca, n 8 (dic. 1990 - feb. 1991), p. 144.

${ }^{16}$ C. Cascajosa, Op. cit., p. 43.

17 En este sentido, podemos ver Twin Peaks como una parte más de una obra multidisciplinar que abarca, como es de sobra conocido, múltiples soportes: plástico, videográfico, televisivo, escrito, digital, en red..

${ }^{18}$ Recordemos la enorme influencia de filósofos como Ralph Waldo Emerson (1803-1882), poetas como Walt Withman y escritores y naturalistas como Henry David Thoreau (con su libro Walden, publicado en 1854) en la mentalidad del estadounidense medio.

19 Que encontraría su más delirante expresión en algunas plasmaciones pseudourbanas surgidas de una serie de propuestas procedentes del llamado New Urbanism, inauguradas en 1981 con el proyecto de Seaside (Florida), lugar que, años después, sería el escenario de rodaje de El show de Truman (The Truman Show, 1981), filme en el que precisamente su director Peter Weir, junto con su guionista Andrew Niccol, proceden a (literalmente) rasgar la capa que recubre todo ese simulacro.

${ }^{20}$ Véase, al respecto, Robert Warshow, "The Gangster as a Tragic Hero", en su libro The Immediate Experience (Enlarged Edition), Cambridge/London, Harvard University Press, 2001.

${ }^{21}$ Que ha conocido -señalémoslo de paso- intensos repuntes en determinados momentos, como durante los primeros años del período de la Gran Depresión que siguió al crack de Wall Street en octubre de 1929, cuando los sentimientos antiurbanos se reforzaron a raíz de la extendida convicción de que habían sido los movimientos espe- culativos de los grandes bancos metropolitanos los causantes de la crisis.

22 Conocida entre nosotros por el estúpido título de Granjero último modelo.

${ }^{23}$ Los paralelismos con su antecesora también son extensibles a su recepción: después de una etapa inicial de buenas audiencias, éstas empezaron a fluctuar de forma patente y sólo su éxito crítico (ganó durante esas cuatro temporadas catorce Emmys, dos de ellos como mejor drama, y un Globo de Oro) hizo que la CBS la mantuviese en antena.

${ }^{24}$ Un ejemplo. $6^{a}$ temporada, capítulo 3: Shofar, so good: Joel expía sus "pecados" en el Jom Kipur presente, pasado y futuro.

25 Otro ejemplo. $6^{\circ}$ temporada, capítulo 1, Cena a las 7.30: Joel es transportado a una realidad alternativa en Manhattan, donde todos los personajes cicelyanos cumplen roles muy distintos, por no decir opuestos, a los habituales.

${ }^{26}$ Cadena generalista estadounidense que posee una red de difusión más pequeña que una network (las tradicionales $A B C, C B S$ y NBC).

${ }^{27}$ Trabajos todos ellos, producidos por $\mathrm{HBO}$, que se inscriben en una líneasíntoma de la ficción televisiva estadounidense, aquella que revisita una y otra vez la propia historia (más o menos lejana), y que el citado canal impulsó desde sus comienzos a través, sobre todo, de los formatos del telefilme y la miniserie: desde La historia de Simon Wiesenthal (Murderers Among Us: The Simon Wiensenthal Story, 1991), pasando por John Adams (2008), hasta la reciente -en todos los sentidos- Game Change (2012), por citar algunos títulos.

${ }^{28}$ V. Quim Casas, "Cineastas en la televisión actual", en Dirigido por, $\mathrm{n}^{\circ}$ 409 (marzo 2011), pp. 50-53.

29 D. Simon, "Introducción", en V.AA., Op. cit., 2010, p. 38.

${ }^{30} \mathrm{C}$. Reviriego, "Pequeña gran pantalla", en Cahiers du cinéma. España, n 29 (dic. 2009), p. 90.

${ }^{31}$ Un excelente catálogo de ejemplos de esas traslaciones puede encontrase en Quim Casas, "Series de televisión de la última década. Un catálogo renovado", en Dirigido por, n 399 (abril 2010), pp. 44-51. 
32 V. Gilles Lipovetsky y Jean Serroy, La pantalla global. Cultura mediática y cine en la era hipermoderna. Barcelona, Anagrama, 2009.

${ }^{33}$ Y aquí cabría hablar de los actuales procesos de retroalimentación que están teniendo lugar entre ambos medios, tema que ya no puede tener cabida dentro de los límites de estas páginas.

${ }^{34}$ Recordémoslo, el guionista de American Beauty (Sam Mendes, 1999) y creador de la ya citada serie $A$ dos metros bajo tierra (Six Feet Under; HBO, 2001-2005).

${ }^{35}$ Así, el tiroteo que vemos en el capítulo piloto será prácticamente el único que tenga lugar a lo largo de la primera temporada: la gente no solía batirse en duelo con pistoleros tan reputados como Seth Bullock (Timothy Oliphant) o Wild Bill Hitchcock (Keith Carradine) a no ser que fuese bastante idiota (como en este caso). En el campamento de Deadwood las muertes serán a degüello y los duelos a golpes (hasta la muerte), mientras que los cadáveres se les darán a los cerdos para que se deshagan de ellos.

${ }^{36} \mathrm{El}$ devenir de la serie hará surgir nuevas conexiones con el cine documental (con la realidad de los hechos) incluso más directas, como ocurre en el séptimo episodio de la tercera temporada (2012), titulado Promise Land: en plena celebración del Mardi Gras, algunos de los protagonistas se encuentran en la calle con Scotty (Scott Roberts) y Kimmy (Kimberly Rivers-Roberts), que se interpretan a sí mismos y cuentan cómo han salido adelante gracias a que un documental que utilizó todas las imágenes grabadas por Kimmy durante la devastación del Katrina (atrapados en su casa, lo perdieron todo y sobrevivieron de milagro) ganó el premio del Festival de Sundance. Unos minutos después, uno de esos personajes
-Delmond Labreaux (Rob Brown), hijo del gran jefe Albert Lambreaux (Clark Peters)- introduce en su ordenador el disco con la grabación del filme que Kimmy les regaló durante el encuentro. A lo largo de los siguientes minutos, las terribles imágenes de la lucha de los Roberts por sobrevivir a la tormenta puntuarán la acción del episodio ante los rostros demudados que, a través de aquéllas, reviven lo sucedido. El filme en cuestión se titula Trouble the Water (Carl Deal y Tia Lessin, 2008) y, efectivamente, se alzó con el Premio del Gran Jurado al mejor Documental en el Festival de Sundance.

${ }^{37}$ A. Petrus, "Perdidos. En algún tiempo, en algún lugar", en Dirigido por, n 399 (abril 2010), pp. 52-56.

${ }^{38} \mathrm{Y}$ en la que la vida puede degenerar en puro acto performativo, vertiente en la que indaga de manera percutante el británico Charlie Brooker en las -hasta el momento- dos temporadas de su serie Black Mirror (2011 y 2013, emitidas por Channel 4).

${ }^{39} \mathrm{H}$. Peter Steeves, "Muriéndonos en nuestros propios brazos: el Liberalismo, el comunitarismo y la construcción de la identidad en Los Soprano", en Richard Greene y Peter Vernezze (eds.), Los Soprano y la filosofía. Mato, luego existo, Madrid, Ariel, 2010, pp. 135-147.

${ }^{40}$ En el octavo capítulo, titulado Iwo Jima, uno de los protagonistas, el sargento de marines Basilone (famoso por sus acciones de guerra y de regreso a Estados Unidos para promover el reclutamiento, aunque posteriormente se encargará del adiestramiento de nuevos soldados), de raíces italianas, intenta ligar en un local con una sargento apellidada Riggi. Ella ironiza sobre los estereotipos: "Soy italiana. Tú eres italiano. Probablemente, los dos somos parientes de Joe DiMaggio. ¿Sabes? Sé dónde podríamos tomar- nos la mejor lasaña de la ciudad. Mira, Los Ángeles está llena de chicas para un chico como tú. Lo harás bien. Feliz caza, sargento".

${ }^{41}$ Un ejemplo podría constituirlo el sargento de marines Nicholas Brody (Damian Lewis), retornado después de ocho años de cautiverio en Irak, que protagoniza Homeland (Showtime, en emisión desde 2011; adaptación a cargo de Howard Gordon y Alex Gansa de la serie israelí Hatufim/Secuestrado). También, en un registro muy distinto, Jonah Gabriel (Chiwetel Ejiofor), el atormentado inspector de policía amnésico (por los efectos de una bala alojada en su cráneo) que protagoniza la miniserie británica The Shadow Line (BBC Two, 2001; creada por Hugo Blick).

${ }^{42}$ Mad Men y The Company constituyen, por otra parte, dos ejemplos muy representativos del uso que de las caligrafías cinematográficas del pasado hacen ciertas series actuales para hablar de nuestra contemporaneidad.

43 Declaraciones recogidas en $E /$ País, 16-06-2010, p. 37.

${ }^{44}$ Art. cit., p. 145. Una rotura que ya había tenido lugar en la literatura y en cierto tipo de cine: "Indagar en lo que no se prefija, como si se escribiera sobre el vacio, que es al fin y al cabo lo que de verdadero tiene la escritura" (J. Ernesto Ayala-Dip, "Vila-Matas en estado puro", en Babelia (El País), 3012-2011, p. 10), pero hablamos ahora de cultura de masas.

${ }^{45}$ V. Gilles Deleuze y Félix Guattari, Mil mesetas. Capitalismo y esquizofrenia. Valencia, Pre-textos, 2000.

${ }^{46} \mathrm{H}$. Aubron, "A dos metros bajo tierra. Los cinco o seis últimos minutos", en Cahiers du cinéma. España, n 1 (mayo 2007), pp. 106-107.

${ }^{47}$ V. Cyril Béghin, "La implicación moral", en Cahiers du cinéma. España, n 50 (nov. 2011), p. 82. 